\title{
Exploration of Switching Behavior of Sharia Banking Customer in Indonesia with Satisfaction as an Intervening Variable
}

\author{
Fetria Eka Yudiana ${ }^{1 *}$ \\ ${ }^{1}$ Faculty of Islamic Economics and Business, IAIN Salatiga, Indonesia
}

\begin{abstract}
The industrial revolution 4.0 will have a great impact on the level of competition in the banking industry including Islamic banking in Indonesia. The analysis of the switching behavior of sharia banking customers is very important to do because environmental change factors greatly affect customers' behavior. This study aims to analyze the switching behavior of Islamic banking customers based on the push-pull mooring factor theory. This study is conducted on Islamic banking customers in Indonesia with the number of respondents of 100 people. This study uses a purposive sampling technique. The research instrument in the form of a questionnaire has been tested valid and reliable which is arranged based on strong indicators from the theoretical studies and previous research. Hypothesis test using path analysis proves that customers' perception of the reward level on deposits/savings, the reputation of Islamic banks, service quality and satisfaction are the factors that influence the switching behavior of sharia banking customers. The results of this study show that customers' perceptions of the reward level on deposits/savings and the reputation of Islamic banks are the factors that have a very positive effect on customer satisfaction of Islamic banks. Customers' satisfaction with Islamic bank products and services can be an intervening variable to the Islamic banking customers switching behaviour.
\end{abstract}

Keywords: customers' perceptions of deposit/savings rewards, sharia bank reputation, sharia bank service quality, customers' satisfaction, switching behavior of sharia banking customer

\section{Introduction}

Technological advancements have pushed the world towards the digital age and pushed for a revolution in the service process in the banking industry. Islamic banking is a business unit that must adapt to these changes. The industrial revolution 4.0 is marked by the emergence of an era of disruption in all aspects of life. Islamic banking is a bank that operates based on sharia principles. In principle, Islamic banks operate based on sharia provisions such as interest-free / usury, gharar (uncertainty) and maisir (gambling). Besides that, Islamic banks

\footnotetext{
* Corresponding author: fetria belsa@yahoo.com
} 


\section{$A \mathrm{IC} \quad$ Annual International Conference \\ on Islamic Economics and Business, 2021}

also run the principle of social welfare as a priority. The challenge for the financial services sector is relatively homogeneous, with low differentiation levels, especially the low level of sharia financial literacy, including for the Muslim community (Kamarulzaman and Madun, 2013; Muslim and Isa, 2008). The community still believes that there is no significant difference between Islamic banks and conventional banks (Haron, 2007). Based on this fact, the opportunity to switch customers will be very high, customers will choose a bank that provides services and service satisfaction. The researcher identifies various factors that have an impact on the process of choosing a bank and customer satisfaction. In service industries such as Islamic banks, service quality is an important factor that affects the level of customer satisfaction or customer satisfaction. According to Ahmossawi (2001) quality is the main key factor for creating customer satisfaction.

Customer switching behavior is caused by many factors (Abdullah et al., 2012), the main factors driving customers to switch to Islamic banking are religious factors (Haron et al, 1994; Metawa and Almossawi, 1998; Almossawi, 2001; Bank Indonesia 2005; Dusuki and Abdullah, 2007). Religion and adherence to sharia law are the main reasons for choosing sharia banking services in Jordan (Naser, K., Jamal, A. and Al-Khatib, L., 1999). The influence of religious values (in this case Islam) on the buying behavior of a Muslim is very strong not only limited to the issue of halal or haram. Besides religious factors, it is very important to understand other factors that influence customer satisfaction so that Islamic banks can compete with conventional banks.

With increasingly fierce competition, Islamic banks must be able to retain customers and attract new customers. From many previous studies on switching behavior, there are still very limited studies using religious perspectives, especially in Indonesia. To fill in the research lack this study uses the basis of a religious perspective in analyzing customer switching behavior. This study focuses on what factors affect the level of customer satisfaction in Islamic banks and then how does the level of satisfaction affect customer switching behavior. The purpose of this study is to identify the factors that influence customer switching behavior and simultaneously analyze the influence of these factors on switching behavior with satisfaction as an intervening variable.

\section{Literature Review}

\subsection{Customer Satisfaction}

According to Sunyoto (2014:227), customer satisfaction is the level of one's feelings after comparing (the performance or results) felt compared to his expectations. Customers can experience one of three general levels of satisfaction that is if performance is below expectations, customers will feel disappointed but performance according to customer expectations will feel satisfied and if performance can exceed expectations, customers will feel very satisfied happy or happy (Kotler, 1997).

Band in Belloh and Liem (2011) in Annisa (2018) Customer satisfaction is a level where the needs, desires, and expectations of customers can be met which will result in repeat purchases or continued loyalty. Hansemark and Albinsson (2004) state overall satisfaction as customer attitudes or behavior towards service providers, or emotional reactions to differences between what consumers imagine and what they get, regarding the fulfillment of several desires, needs or dreams. 


\section{$A \mathrm{IC} \quad$ Annual International Conference \\ on Islamic Economics and Business, 2021}

\subsection{Customer Switching Behavior}

In conventional literature, we are familiar with switching behavior. Consumer switching behavior is based on capitalist economic theory. Many definitions of switching behavior have been suggested by previous researchers. Switching behavior is a process or decision to end a relationship with a service provider for a specific reason by stopping buying and consuming goods and services and establishing relationships with other service providers (Vyas, 2014) (Raitani, S., 2013). Switching behavior occurs if consumers stop making transactions and take the initiative to establish relationships or transact with other service providers (Oyeniyi and Abiodun, 2010). Behavior switching is a transfer to a service provider consisting of replacing the current service provider with another service provider (Bansal \& Taylor, 1999). Jaya (2016: 117) states for the banking industry, switching behavior is the behavior of customers to move from one bank to another with or without closing products contained in the previous bank.

According to Bolton and Bronkhorst (1995), switching behavior mimics a customer's decision to stop making a purchase/business with a particular service or subscribe to a full service. Customers will withdraw or switch to another bank depending on their satisfaction with certain types of services. (Clemes et al., 2010) in Rama (2017) identified eight factors that contribute to customer movement in the Chinese retail bank industry, including price, reputation, service quality, effective advertising, forced migration, location distance, cost transfer, and demographic characteristics.

\subsection{Reputation}

Bank's reputation is a function of financial performance, production quality, service quality, management effectiveness, or a combination of some of these elements that attract consumers' attention (Rao, 1994) in Jaya (2016). According to Clemes (2007) reputation depends on three elements, namely bank reliability, trust in banks, and bank financial stability. The coefficient value for reputation states that a bank with a bad reputation makes customers more likely to move. Shamma (2012) in Jaya (2016) states the high upheaval in the business environment, increasing public expectations, and pressure from various stakeholders greatly influences the importance of reviewing and managing the company's reputation. Intense competition offers consumers more variety and choices in the market. Thus, reputation is identified by companies in the service sector as an important part of their competitive strategy (Kumar, 2014)

\subsection{Quality of Service}

According to Rama (2017), service quality is defined as the difference between the customer's expectations of the service to be received and the perception of the actual service received. Quality of service has become an important factor for success and survival in the banking industry. Many banks have implemented service quality as a sustainable competitive advantage because the products offered by most banks are almost the same and imitated (Clemes, 2007). In the context of Islamic banks, according to Awan (2011) in Rama (2017), most customers assess product quality and service quality to be the main factor in making decisions to choose Islamic banks. The dimensions of service quality according to Tjiptono (2001: 70) in Istiqomah (2018) conclude that there are five dimensions of ServeQual (Service Quality) that are used to measure service quality, namely: tangibility, reliability, responsiveness, assurance, and empathy. Tangibility is a physical component including physical facilities and personnel. Reliability includes the ability to provide services properly. Responsiveness is the desire of employees to help customers and provide the best service, 


\section{$A \mathrm{IC} \quad$ Annual International Conference \\ on Islamic Economics and Business, 2021}

assurance is the ability and knowledge possessed by employees of Islamic banks so that they provide excellent service. Empathy is the ability to serve with a high level of care.

\subsection{Prior Research Review}

In understanding the study of switching behavior, it is important to realize that the decision to switch individuals is based on different reasons. Research on switching behavior is mostly based on migration theory, where the underlying motive for switching is caused by negative elements at the beginning, positive elements at the destination and also elements that might hinder or debate switching decisions. In the application of migration theory, several theoretical models have been developed such as service switching behavior reasons, understanding of certain behavioral aspects (planned behavior models). The following is a summary of the literature review from previous research on switching behavior in the banking industry in several countries.

Table. Literature review on switching behavior in the banking industry

\begin{tabular}{|c|c|c|c|c|}
\hline No. & Researcher & $\begin{array}{c}\text { Relationship between } \\
\text { variables }\end{array}$ & Influence & Country \\
\hline \multicolumn{5}{|c|}{ Customer Satisfaction and Switching Intention } \\
\hline 1 & Bansal et.al. (2005) & $\begin{array}{c}\text { Customer Satisfaction and } \\
\text { Switching Intention }\end{array}$ & Negative significant & $\begin{array}{l}\text { Cross } \\
\text { country }\end{array}$ \\
\hline 2 & Ceesay (2017) & $\begin{array}{l}\text { Customer Satisfaction and } \\
\text { Switching Intention }\end{array}$ & Negative significant & Gambia \\
\hline 3 & Walsh et al (2006) & $\begin{array}{l}\text { Customer Satisfaction and } \\
\text { Switching Intention }\end{array}$ & Positive significant & $\begin{array}{l}\text { Cross } \\
\text { country }\end{array}$ \\
\hline 4 & $\begin{array}{l}\text { Gurjeet Kaur, R.D. } \\
\text { Sharma \& Neha } \\
\text { Mahajan (2011) }\end{array}$ & $\begin{array}{l}\text { Customer Satisfaction and } \\
\text { Switching Intention }\end{array}$ & Negative significant & India \\
\hline 5 & $\begin{array}{l}\text { Hashim \& Latifah } \\
(2010)\end{array}$ & $\begin{array}{c}\text { Customer Satisfaction and } \\
\text { Switching Intention }\end{array}$ & Negative significant & Indonesia \\
\hline \multicolumn{5}{|c|}{ Customer Satisfaction and Switching behaviour } \\
\hline 1 & Clemes et al. (2010) & $\begin{array}{c}\text { Customer Satisfaction and } \\
\text { Switching behavior }\end{array}$ & Negative significant & $\begin{array}{c}\text { New } \\
\text { Zealand }\end{array}$ \\
\hline \multicolumn{5}{|c|}{ Quality of Service and Switching Intention } \\
\hline 1 & Ceesay (2017) & $\begin{array}{l}\text { Quality of Service and } \\
\text { Switching Intention }\end{array}$ & Negative significant & Gambia \\
\hline 2 & $\begin{array}{l}\text { Gurjeet Kaur, R.D. } \\
\text { Sharma \& Neha } \\
\text { Mahajan (2011) }\end{array}$ & $\begin{array}{l}\text { Quality of Service and } \\
\text { Switching Intention }\end{array}$ & Signific & India \\
\hline 3 & $\begin{array}{l}\text { Malik \& Naeem, } \\
(2011)\end{array}$ & $\begin{array}{l}\text { Quality of Service and } \\
\text { Switching Intention }\end{array}$ & $\begin{array}{c}\text { Negative } \\
\text { significant }\end{array}$ & $\begin{array}{l}\text { Cross } \\
\text { country }\end{array}$ \\
\hline 4 & Berry, et. al. (1988) & $\begin{array}{l}\text { Quality of Service and } \\
\text { Switching Intention }\end{array}$ & $\begin{array}{l}\text { Negative } \\
\text { significant }\end{array}$ & $\begin{array}{l}\text { Cross } \\
\text { country }\end{array}$ \\
\hline \multicolumn{5}{|c|}{ Quality of Service and Switching Behavior } \\
\hline 1 & $\begin{array}{l}\text { Pirzada S.S et al, } \\
(2014)\end{array}$ & $\begin{array}{c}\text { Quality of Service and } \\
\text { Switching Behavior }\end{array}$ & Positive significant & $\begin{array}{l}\text { Cross } \\
\text { country }\end{array}$ \\
\hline 2 & $\begin{array}{l}\text { Suryani dan Chaniago } \\
(2011)\end{array}$ & $\begin{array}{c}\text { Quality of Service and } \\
\text { Switching Behavior }\end{array}$ & Positif significant & Indonesia \\
\hline 3 & Khan et al (2010) & $\begin{array}{l}\text { Quality of Service and } \\
\text { Switching Behavior }\end{array}$ & Positive significant & Pakistan \\
\hline 4 & Clemes et al. (2010) & $\begin{array}{l}\text { Quality of Service and } \\
\text { Switching Behavior }\end{array}$ & Negative significant & China \\
\hline
\end{tabular}




\section{$\mathrm{AIC} \overline{\overline{I E B}}$ \\ Annual International Conference \\ on Islamic Economics and Business, 2021}

\begin{tabular}{|c|l|c|c|c|}
\hline 5 & Clemes et al. (2007) & $\begin{array}{c}\text { Quality of Service and } \\
\text { Switching Behavior } \\
\text { Quality of Service and } \\
\text { Switching Behavior }\end{array}$ & Negative significant & $\begin{array}{c}\text { New } \\
\text { Zealand }\end{array}$ \\
\hline 6 & Colgate \& Lang (2011) & $\begin{array}{c}\text { Cross } \\
\text { country }\end{array}$ \\
\hline 7 & $\begin{array}{l}\text { Ramaiger S. \& } \\
\text { Jayalakshmy R. (2012) }\end{array}$ & $\begin{array}{l}\text { Quality of Service and } \\
\text { Switching Behavior }\end{array}$ & Not significant & Malaysia \\
\hline \multicolumn{4}{|c|}{ Quality of service and customer satisfaction } \\
\hline 1 & $\begin{array}{l}\text { Wijaya \& Budiman } \\
(2018)\end{array}$ & $\begin{array}{l}\text { Quality of service and } \\
\text { customer satisfaction }\end{array}$ & Positive significant & Indonesia \\
\hline
\end{tabular}

\section{Research Model}

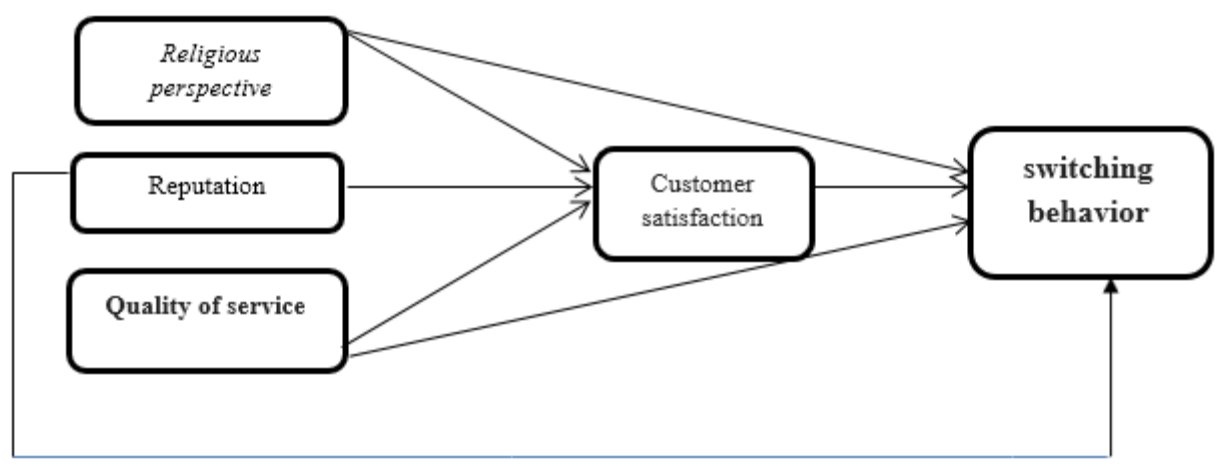

Fig.1 Research Framework

\section{Customer satisfaction and switching behavior}

Customer satisfaction is a form of fulfilling customer expectations for the products and services provided by banks. Kotler (2013) defines consumer satisfaction depends on the performance of products and services that can meet consumer expectations. Ceesay (2017) proves that satisfaction has a significant negative effect on customer switching behavior in Gambia. Gurjeet Kaur, R.D. Sharma \& neha Mahajan (2011) also need the same thing in India that satisfaction negatively affects customer switching behavior. Rama (2017), Rahayu (2017), Chandra (2017) in their research stated that customer satisfaction had a significant positive effect on customer switching behavior. Based on the facts above, the research hypothesis is:

H1: Customer satisfaction has a significant negative effect on customer switching behavior

\section{Religious perspective, customer satisfaction, and switching behavior}

Michael D. Clemes, et al (2010) concluded that reputation, service quality, influences customer switching behavior. Likewise, (Sonika Raitani ,2014) (Vyas, 2014)concluded that reputation, customer satisfaction, service quality, service products, significantly influence customer switching behavior. Metawa and Almossawi (1988) concluded that there are two factors considered in choosing a bank, namely a bank that is principled in Islamic law and the level of profitability. Then Dasuki and Abdullah (2006) concluded that religious factors were a key factor in the customer decision-making process. (Rizwan et al., 2014) (Ashraf, 2014)found there was a positive influence of religious perspective on customer satisfaction. Based on the facts above, the hypothesis of this study was:

$\mathrm{H} 2$ : Religious perspective has a significant negative effect on customer switching behavior

H3: Religious perspective has a significant positive effect on customer satisfaction

H4: Customer satisfaction mediates the effect of a religious perspective on customer switching behavior. 


\section{Reputation, customer satisfaction and switching behavior}

Research conducted by (Zhang et al., 2012), Clemes (2007), Arsalan (2010), Kumar (2014), Aldyati (2014) states that reputation has a significant positive effect on customer switching behavior. Before buying products from a bank, customers will look for information about the state of the bank, how the bank's reputation in serving its customers. Reputation is the communication process created by the company and specific messages about the mission, vision, goals and core values given to customers. Reputation influences customer satisfaction and customer loyalty (Bravo, 2009 in Nursiana, 2015). This is supported by research conducted by Nursiana (2015) and Simamora (2007) which states that reputation has a significant positive effect on customer behavior. Based on the facts above, the research hypothesis is as follows:

H5: Reputation has a significant negative effect on customer switching behavior.

H6: Reputation has a significant positive effect on customer satisfaction

H7: Customer satisfaction mediates the effect of reputation on customer switching behavior

\section{Quality of service, customer satisfaction, and switching behavior}

Moon, in Bansal 2005 in Sientia, 2012 defines the driving factors are the factors that motivate customers to move from old service providers which are assumed to have a negative influence on the quality of life indicators. In services, this driving factor can be attributed to the low quality of service at service providers, thus encouraging customers to move to new service providers. In a study conducted by Rahayu (2017), Kumar (2014), Rama (2017), Jaya (2016) stated that service quality has a significant influence on consumers' switching behavior according to the push-pull theory above. Tjiptono (2002) in Prasetio (2012) revealed that quality has a close relationship with customer satisfaction. A company with a high level of customer satisfaction provides a high level of customer service. Customer satisfaction is closely related to service quality. Companies need to pay more attention to the quality of service because satisfaction with the quality of service to one another is difficult to imitate. This is supported by research conducted by Prasetyo (2012), Simamora (2007), Cokorda (2018), and Madona (2018) that service quality has a positive effect on customer satisfaction. According to Solomon, in Listyarini, 2010 in Sientia (2012), the perceived quality of a product or service will directly affect the satisfaction of customer purchases and loyalty to certain companies. Marketers who do not pay attention to the quality of the product or service offered to have a risk with customer loyalty so that if consumers feel dissatisfied with the quality of the product or service provided, they will leave the product or service provider.

This theory is supported by research conducted by Rahayu (2017) which states that customer satisfaction can partially mediate the effect of service quality on customer switching behavior. From the facts above, the research hypothesis is as follows:

H8: Service quality has a significant negative effect on customer switching behavior

H9: Service quality has a significant positive effect on customer satisfaction

H10: Customer satisfaction mediates the effect of service quality on customer switching behavior.

\section{Method}

This research is a field research with a descriptive quantitative approach. This research data uses primary data. The respondents of this study are sharia banking customers in Indonesia. The sampling technique of this study was purposive accidental sampling, which is a sampling technique with the application of certain criteria that fit the research objectives and the subject is available to researchers when data collection is done. The criteria used for determining respondents are as follows: (1) willing to be a research respondent by filling out and sending 


\section{$A I \overline{I E B} \quad$ Annual International Conference \\ on Islamic Economics and Business, 2021}

back the questionnaire sent online via Whatsapp; (2) Become a customer of Islamic banking in Indonesia.

The determination of the number of samples in this study was assessed from population characteristics. The population in this study is homogeneous so that it is not required a large sample. Although the use of large numbers of samples is highly recommended consideration of various time constraints, so that researchers try to take a minimum sample with the terms and rules of statistics still being met as recommended by Isaac and Michael (Sukardi, 2004: 55). By using a certain formula (see Sukardi, 2004: 55-56), Isaac and Michael give the final results of the number of samples to the population of $10-100,000$ respondents. This research consists of independent variables, intervening variables, and dependent variables. The research instrument in the form of a questionnaire was developed based on indicators that have been used in previous studies

\subsection{Respondent Statistics Data}

Table. Research Respondent Profile Table

\begin{tabular}{|c|c|c|}
\hline \multicolumn{2}{|c|}{ Demographic profile } & Percentage \\
\hline \multirow{2}{*}{ Islamic bank products } & deposit & $96,1 \%$ \\
\cline { 2 - 3 } & Etc & $3,9 \%$ \\
\hline \multirow{2}{*}{ Gender } & Male & $53,9 \%$ \\
\cline { 2 - 3 } Marital status & Female & $46,1 \%$ \\
\cline { 2 - 3 } & Married & $76,5 \%$ \\
\cline { 2 - 3 } & Single & $19,6 \%$ \\
\hline \multirow{2}{*}{$\begin{array}{c}\text { Distribution of the respondent's } \\
\text { income }\end{array}$} & Divorce & $3,9 \%$ \\
\hline \multirow{3}{*}{$\begin{array}{c}\text { Distribution of domicile } \\
\text { Rp. 1 million - Rp. 5 million }\end{array}$} & $43,1 \%$ \\
\cline { 2 - 3 } & In the city & $48 \%$ \\
\cline { 2 - 3 } & In the district town & $23,5 \%$ \\
\cline { 2 - 3 } & In the district & $8,8 \%$ \\
\hline \multirow{2}{*}{\begin{tabular}{c} 
Respondent's employment status \\
\cline { 2 - 3 }
\end{tabular}} & in the big city & $56,9 \%$ \\
\cline { 2 - 3 } & Civil Servants (PNS) & $18,6 \%$ \\
\cline { 2 - 3 } & Private employees & $12,7 \%$ \\
\hline & Entrepreneur & $11,8 \%$ \\
\hline
\end{tabular}

Source: Primary Data Processed, 2019

Respondents who filled out this research questionnaire were 102 Islamic bank customers spread throughout Indonesia. By using the accidental purposive sampling technique, those who met the criteria were 100 respondents.

\section{Result and Discussion}

Data were analyzed using regression with intervening variables so that the path of analysis was used. The analysis was carried out through stages ranging from research instrument testing, statistical tests and hypothesis testing with multiple tests. First, Testing the reliability and validity of the construction and research instrument question items. Test the validity by conducting a bivariate correlation between each indicator score with the total construct score performed by the significance test by comparing the value of $r$ arithmetic with $r$ table for degree of freedom $(\mathrm{df})=\mathrm{n}-2$. In this case, the amount of df can be calculated from 100-2 or $\mathrm{df}=98$ and alpha 0.05 is obtained $\mathrm{r}$ table $=0.1966$. if the $\mathrm{r}$ count (for the question items can be seen in the corrected item-total correlation question column) is greater than the $r$ table and the value of $r$ is positive, then the question item is said to be valid. While the reliability test 


\section{$A I \overline{C E B} \quad$ Annual International Conference \\ on Islamic Economics and Business, 2021}

by seeing that each Cronbach Alpha variable $\geq 0.60$; the tolerance limit of the cross-loading value of each variable is between 0.60 - 0.70 (Hair et. al., 2014). Religious perspective (X1) $=0.784$; Reputation $(\mathrm{X} 2)=0.822$; service quality $(\mathrm{X} 3)=0.652$; customer satisfaction $(\mathrm{Z})=$ 0.775 ; behavior of migrating $(\mathrm{Y})=0.794$; thus these variables can be said to be reliable. The coefficient of determination (R2) of model A where religious perspective, reputation, service quality, and customer satisfaction as predictor variables is $=0.871$; This indicates that $87.1 \%$ of the predictor variables in Model A can predict sharia banking customer switching behavior. While the coefficient of determination of model B where religious perspective, reputation, service quality as predictor variables is $=0.780$; This indicates that $78 \%$ of the predictor variables in Model B can predict customer satisfaction of Islamic banking. The Error of the Estimate (SEE) standard is 1.0899. The smaller the SEE value will make the regression model more precise in predicting the dependent variable.

ANOVA test or F test obtained the calculated F value of 161.018 with a probability of 0,000 . Because the probability is much smaller than 0.05 , the regression model can be used to predict customer switching behavior (Y) or it can be said that the Religious Perspective (X1), reputation (X2), service quality (X3), customer satisfaction (Z) together affects the customer switching behavior (Y). The influence of each independent variable on the dependent variable was carried out by the t-test.

Table 1. T-test with the dependent variable customer switching behavior Coefficients $^{\mathrm{a}}$

\begin{tabular}{|l|c|c|c|c|c|}
\hline \multirow{2}{*}{ Model } & \multicolumn{2}{|c|}{$\begin{array}{c}\text { Unstandardized } \\
\text { Coefficients }\end{array}$} & $\begin{array}{c}\text { Standardized } \\
\text { Coefficients }\end{array}$ & \multirow{2}{*}{$\mathrm{T}$} & Sig. \\
\cline { 2 - 4 } & $\mathrm{B}$ & Std. Error & Beta & & \\
\hline (Constant) & -4.474 & 1.664 & & -2.689 & .008 \\
Religious Prespective & -.315 & .070 & .301 & 4.489 & .000 \\
Reputation & -.122 & .049 & .132 & 2.496 & .014 \\
Quality of service & -.109 & .037 & .120 & 2.949 & .004 \\
Customer satisfaction & -.554 & .082 & .529 & 6.756 & .000 \\
\hline
\end{tabular}

a. Dependent Variable: switching behavior

Source: Primary data processed, 2019

From the table above it can be seen that all variables of Religious Perspective, Reputation, service quality, customer satisfaction have a significant effect on customer switching behavior variables.

Table 2. T-test with the dependent variable customer satisfaction Coefficients $^{\mathrm{a}}$

\begin{tabular}{|l|c|c|c|c|c|}
\hline \multirow{2}{*}{ Model } & \multicolumn{2}{|c|}{$\begin{array}{c}\text { Unstandardized } \\
\text { Coefficients }\end{array}$} & $\begin{array}{c}\text { Standardized } \\
\text { Coefficients }\end{array}$ & \multirow{2}{*}{$\mathrm{T}$} & \multirow{2}{*}{ Sig. } \\
\cline { 2 - 4 } & $\mathrm{B}$ & Std. Error & Beta & & .217 \\
\hline \multirow{2}{*}{1 (Constant) } & 2.552 & 2.056 & & 1.241 & .000 \\
Religious Prespective & .634 & .059 & .635 & 10.819 & .000 \\
Reputation & .262 & .055 & .297 & 4.795 & .007 \\
Quality of service & .123 & .044 & .142 & 2.782 & \\
\hline
\end{tabular}

a. Dependent Variable: customer satisfaction

Source: Primary data processed, 2019 


\section{$A I \overline{C E B} \quad$ Annual International Conference \\ on Islamic Economics and Business, 2021}

From the table above it can be seen that all Religious perspectives, Reputation, Service quality have a significant positive effect on customer satisfaction.

\section{Path Analysis}

The effect of mediation is shown by the multiplication coefficient (p2 x p3), significant or not influence is tested by sobelt test as follows: Ghozali (2018: 250)

$$
S \mathrm{p}^{2} \mathrm{p}^{3}=\sqrt{p 3^{2} S p 2^{2}+p 2^{2} S p 3^{2}+S p 2^{2} S p 3^{2}}
$$

Based on the results of $S p^{2} p^{3}$ we can calculate the value of t mediation effect statistics with the following formula:

$t=\frac{\mathrm{p}^{2} \mathrm{p}^{3}}{\mathrm{Sp}^{2} \mathrm{p}^{3}}$

If the value of the $t$ arithmetic $>t$ table with a significant level of 0.05 is 1.66 , it can be concluded that there is a mediating effect. Based on the SPSS path test results can produce a path analysis model as follows:

From table Regresi $t$-test (1) dan (2) the value $e 1=\sqrt{(1-0,773)}=0,476$ and $e 2=$ $\sqrt{(1-0,866)}=0,366$

\section{The Influence of Religious Perspective On Sharia Bank Customer Switching Behavior With Customer Satisfaction As An Intervening Variable.}

The magnitude of the direct effect is 0.315 while the indirect effect must be calculated, that is $(0.634 \times 0.554)=0,351236$. With a total effect of $0.315+0,351236=0.666236$

The effect of mediation shown by the multiplication coefficient (p2 x p3) for Religious perspective of 0,351236 test results with Sobel test shows the value of $t=5.702$ is greater than $t$ table with a significance level of 0.05 that is equal to 1.960 then it can be concluded that there is an influence mediation. Effect of Reputation on Sharia Bank Customers' switching behavior with customer satisfaction as an intervening variable. The magnitude of the direct effect is 0.122 while the indirect effect must be calculated $(0.262 \times 0.554)=$ 0.145148 . With a total effect of $0.122+0.145148=0.267148$

The effect of mediation shown by the multiplication coefficient $(\mathrm{p} 2 \times \mathrm{p} 3)$ for the reputation of 0.145148 Sobel test results showed the value of $t$ count $=3.870$ is greater than $t$ table with a significance level of 0.05 that is equal to 1.960 so there is a mediating effect.The effect of service quality on sharia bank customers' switching behavior with customer satisfaction as an intervening variable. The magnitude of the direct effect is 0.109 while the indirect effect must be calculated $(0.123 \times 0.554)=0.068142$. With a total effect of $0.109+0.068142=$ 0.177142 . The effect of mediation shown by the multiplication coefficient ( $\mathrm{p} 2 \times \mathrm{p} 3$ ) for customer satisfaction of 0.068142 Sobel test results t-test value $=2.741$ is greater than t table with a significance level of 0.05 that is equal to 1.960 so there is a mediating effect. The complete results of the hypothesis test of this study are as follows: 
Table 3. Research Hypothesis Test Table

\begin{tabular}{|c|c|c|}
\hline No. & Hypothesis & Hypothesis Test Results \\
\hline H1 & $\begin{array}{l}\text { Customer satisfaction has a significant negative } \\
\text { effect on customer switching behavior }\end{array}$ & significant \\
\hline $\mathrm{H} 2$ & $\begin{array}{l}\text { Religious perspective has a significant negative } \\
\text { effect on customer switching behavior }\end{array}$ & significant \\
\hline $\mathrm{H} 3$ & $\begin{array}{l}\text { Religious perspective has a significant positive } \\
\text { effect on customer satisfaction }\end{array}$ & significant \\
\hline $\mathrm{H} 4$ & $\begin{array}{l}\text { Customer satisfaction mediates the effect of a } \\
\text { religious perspective on customer switching } \\
\text { behavior. }\end{array}$ & significant \\
\hline H5 & $\begin{array}{l}\text { Reputation has a significant negative effect on } \\
\text { customer switching behavior. }\end{array}$ & significant \\
\hline H6 & $\begin{array}{l}\text { Reputation has a significant positive effect on } \\
\text { customer satisfaction }\end{array}$ & significant \\
\hline $\mathrm{H} 7$ & $\begin{array}{l}\text { Customer satisfaction mediates the effect of } \\
\text { reputation on customer switching behavior }\end{array}$ & significant \\
\hline $\mathrm{H} 8$ & $\begin{array}{l}\text { Service quality has a significant negative effect on } \\
\text { customer switching behavior }\end{array}$ & significant \\
\hline H9 & $\begin{array}{l}\text { Service quality has a significant positive effect on } \\
\text { customer satisfaction }\end{array}$ & significant \\
\hline H10 & $\begin{array}{l}\text { Customer satisfaction mediates the effect of service } \\
\text { quality on customer switching behavior. }\end{array}$ & significant \\
\hline
\end{tabular}

\section{Classic assumption test}

The normality test uses the Kolmogorov-Smirnov non-parametric statistical test which states that the Asymp.Sig (2-tailed) is 0.200 while the significant level used is 0.05 . Heteroscedasticity test scatterplots graph shows that the points spread randomly and spread both above and below the number 0 on the $\mathrm{Y}$ axis.

- Multicollinearity test Standard error of the Subjective norm (X2) variable has a standard error of more than one $(1,509)$ indicating there is multicollinearity.

- The Tolerance value of the four independent variables is greater> 0.10 so that there is no multicollinearity.

- VIF (Variance Inflation Factor) value of the four independent variables $<10.00$ so that there is no multicollinearity.

\section{Discussion of research results}

The purpose of this study is to explore the factors that influence sharia banking customers' switching behavior. The results of this study indicate that the religious perspective, the reputation of Islamic banks and the quality of Islamic banking services affect the satisfaction of Islamic bank customers and the switching behavior of Islamic bank customers. The results 


\section{$A \overline{I E B} \quad$ Annual International Conference \\ on Islamic Economics and Business, 2021}

of this study indicate that there is a significant negative relationship and influence between satisfaction with customer switching behavior. This shows that satisfied customers will remain customers of Islamic banks and the desire to move to conventional banks is very small. The results of this study are in line with previous studies conducted by Ceesay (2017); Gurjeet Kaur, R.D. Sharma \& Neha Mahajan (2011); which proves that customer satisfaction has a negative effect on switching behavior.

The second and fourth hypotheses of this study, state that there is a significant negative effect of religious perspective on customer switching behavior. That satisfaction the customer is an intervening variable between religious perspective and moving behavior. This means that the influence of the level of customer satisfaction is greater than the direct effect of religious perspective on the behavior of migrating. Rizwan et al (2014) also proved that religion has a positive effect on customer attitudes towards Islamic banks, which indicates that religious perspective has a negative effect on the switching behavior of Islamic bank customers. The third hypothesis is proven that a religious perspective has a significant positive effect on customer satisfaction. The results of this study are in line with Ashraf (2014) which proves that religious perspective influences customer satisfaction of Islamic banks.

The fifth hypothesis is that the reputation of a good and strong Islamic bank will weaken the customer's decision to move to a conventional bank. The sixth hypothesis is that Islamic banks' reputation has a positive effect on customer satisfaction. This research is supported by several previous studies including Davis et al (2002) which states that bank image has a positive effect on customer satisfaction. Furthermore, the seventh hypothesis is proven that customer satisfaction can mediate the negative influence of the reputation of Islamic banks on the switching behavior of Islamic bank customers. This means that the variable of customer satisfaction has a stronger influence based on the direct influence of reputation on the switching behavior of Islamic bank customers. The influence of a bad reputation will be mediated by customer satisfaction. This means that if the customer is satisfied with the services of Islamic banks, the influence of a less good reputation will be minimized.

\section{Conclusion}

\subsection{Implementation and Recomendations}

In the banking industry, there is a very complex competition between conventional banks and Islamic banks. Indonesia is one of the countries implementing a dual banking system. A very small level of product differentiation will add to the opening level of interbank customer transfers. The level of loyalty is getting smaller. The customer has full power to determine his choice of whether to survive or move to another bank. Customer satisfaction has a very negative effect on sharia bank customers' switching behavior. Customer satisfaction is strongly influenced by the religious perspective, reputation of Islamic banks and the quality of Islamic banking services. So that these three factors must be maintained and enhanced by Islamic banks to be able to increase customer satisfaction. This study also proves that customer satisfaction has a significant negative impact on the switching behavior of Islamic bank customers. At present conventional banks tend to adopt

Islamic banking system because it sees a pretty good market gap. The public holds that Islamic banks are no different from conventional banks in terms of products and systems. Islamic banks must increase awareness and literacy of Islamic financial society through various social activities. 


\subsection{Weaknesses and Suggestions for Further Research}

The research data was taken by accidental purposive sampling with a relatively short time and less general. The level of generalization of research respondents will better reflect objectivity. The number of research samples that only 100 people lack.

\section{References}

Abdullah, A. A., Sidek, R., \& Adnan, A. A. (2012). Perception of non-Muslims customers towards Islamic banks in Malaysia. International Journal of Business and Social Science, 3(11), 151-163.

Ashraf, M. G. (2014). Include the Position of Islamic Banking, Service Quality, Satisfaction, Trust and Loyalty in the Context of an Integrated Model for Islamic Finance. European Journal of Business and Management, 6(17), 156-169.

Bansal, H. S., \& Taylor, S. F. (1999). The service provider switching model (SPSM). A model of consumer switching behavior in the services industry. Journal of Service Research, 2, 200-218.

Ceesay, L. (2017). Customer- Band Association: Determinants of Consumer Bank Switching Intention, Case of the Gambia Retail Banking Sector. J Bus Fin Aff 6: 295. https://doi.org/10.4172/2167-0234.1000295

Clemes, M. D., Gan, C., \& Zhang, D. (2010). Customer switching behavior in the Chinese retail banking industry. International Journal of Bank Marketing, 28, 519-546.

Rizwan, M., Yaseen, G., Nawaz, A., \& Hussain, L. (2014). Incorporating Attitude towards Islamic Banking in an integrated Service Quality, Satisfaction, Trust and Loyalty Model. International Journal of Accounting and Financial Reporting, 4(2), 456.

Vyas, V. (2014). Drivers of customers' switching behaviour in Indian banking industry. International Journal of Bank Marketing (Int $J$ Bank Market), 32(4). https://doi.org/10.1108/IJBM-04-2013-0033

Zhang, K. Z. K., Cheung, C. M. K., \& Lee, M. K. O. (2012). Online service switching behaviors: The case of blog service providers. Journal of Electronic Commerce Research, 13, 184-197. 